\title{
KONSEP PENDIDIKAN ISLAM BERWAWASAN MULTIKULTURALISME PERSPEKTIF HAR. TILAAR
}

\author{
Nurul Hidayati \\ (IAI Uluwiyah Mojokerto)
}

\begin{abstract}
Abstrak:
Multikulturalisme, sebagai sebuah diskursus, memang merupakan produk kajian ilmuan Barat akan realitas-eksistensial kebudayaan mereka yang heterogen. Namun, ke-khas-an kajian mereka tidak menyentuh aspek-aspek teologis, jika tidak mau disebut Agama. Multikulturalisme hadir ke Indonesia dengan wajah yang berbeda. Ada banyak perspektif, yang kemudian, mengamalgamasikan kepentingan faham keagamaan, dengan sumber kebudayaan yang dikaji di Barat melalui cultural studies-nya. Kendati demikian, masyarakat Indonesia tidak bisa dilepaskan dari homogenitas, pluralitas, dan multi-kebudayaan. Oleh sebab itulah, para pendiri bangsa memiliki slogan Bhinneka Tuggal Ika, dari hal yang berbeda-beda, namun memiliki satu tujuan yang sama. Slogan ini, terkadang, tidak disadari oleh seluruh masyarakat Indonesia. Untuk itulah, HAR Tilaar menawarkan sebuah konsep pendidikan yang dibasiskan kepada pengenalan dan pemahaman akan perbedaan kebudayaan yang dimiliki Indonesia. Tulisan ini berusaha mengkaitkan gagasan Tilaar ini dengan fenomena konflik yang ada di Indonesia, khususnya, berbasis agama. Melalui pendidikan multikultural, diharapkan, seluruh pemeluk agama menyadari akan tantangan perbedaan yang diciptakan oleh Tuhan.
\end{abstract}

Kata Kunci: Multikulturalisme, Pendidikan, Islam, Konflik. 


\begin{abstract}
:
Multiculturalism as an academic discourse comes from western scholarly tradition regarding their heterogeneus cultural existential-reality. However, the distinguish discourse does not deal with theological aspects, if it is to hesitate to call religion. Multiculturalism comes to Indonesia in a different face. There are so many perspectives to amalgamate religious interest and western culture within cultural studies framework. However, Indonesian cannot be separated from homogeneity, plurality, as well as multi-culturalism. For that reason, the nation's founding father promoted the slogan "Bhinneka Tunggal Ika", unity in diversity. The slogan is sometimes less understood by citizens. This made H.A.R. Tilaar to offer an educational concept based upon introducation and comprehension towards Indonesian cultural diversity. This paper examines the Tilaar's thoughts and religion-based conflict in Indonesia. Multicultural education itself is proposed to shade light for religions's follower regarding the challenge of diversity created by God.
\end{abstract}

\title{
Keywords: Multiculturalism, Education, Islam, Conflict.
}

\section{A. Pendahuluan}

Multikulturalisme dalam pendidikan Islam sangat urgen untuk diteliti. Mengingat masyarakat majemuk Indonesia yang mayoritas penduduknya beragama Islam. Secara sederhana multikulturalisme berarti keberagaman budaya. ${ }^{1}$ Sebenarnya, ada tiga istilah yang kerap digunakan secara bergantian untuk menggambarkan masyarakat yang terdiri keberagaman tersebut baik keberagaman agama, ras, bahasa, dan budaya yang berbeda- yaitu pluralitas (plurality), keragaman (diversity), dan multikulturalisme (multicultural). Ketiga ekspresi itu sesungguhnya tidak merepresentasikan hal yang sama, walaupun semuanya mengacu kepada adanya "ketidaktunggalan". Konsep pluralitas mengandaikan adanya hal-hal yang lebih dari satu (many); keragaman menunjukkan bahwa keberadaan yang "lebih dari satu" itu berbeda-beda, heterogen, dan bahkan tak dapat disamakan. Dibandingkan dua konsep terdahulu, multikulturalisme sebenarnya relatif baru.

Secara konseptual, terdapat perbedaan signifikan antara pluralitas, keragaman, dan multikulturalisme. Inti dari multikulturalisme adalah kesediaan menerima kelompok lain secara sama sebagai kesatuan, tanpa memperdulikan perbedaan budaya, etnik, gender, bahasa, ataupun agama. Apabila pluralitas

${ }^{1}$ Scott Lash dan Mike Featherstone, ed., Recognition and Difference: Politics, Identity, Multiculture (London: Sage Publication, 2002), 2-6. 
sekadar merepresentasikan adanya kemajemukan (yang lebih dari satu), multikulturalisme memberikan penegasan bahwa dengan segala perbedaannya itu mereka adalah sama di dalam ruang publik. Multikulturalisme menjadi semacam respons kebijakan baru terhadap keragaman. Dengan kata lain, adanya komunitas-komunitas yang berbeda saja tidak cukup; sebab yang terpenting adalah bahwa komunitas-komunitas itu diperlakukan sama oleh negara. Oleh karena itu, multikulturalisme sebagai sebuah gerakan menuntut pengakuan (politics of recognition) terhadap semua perbedaan sebagai entitas dalam masyarakat yang harus diterima, dihargai, dilindungi serta dijamin eksistensinya.

Diversitas dalam masyarakat modern bisa berupa banyak hal, termasuk perbedaan yang secara alamiah diterima oleh individu maupun kelompok dan yang dikonstruksikan secara bersama dan menjadi semacam common sense. Perbedaan tersebut menurut Bikhu Parekh bisa dikategorikan dalam tiga hal salah satu atau lebih dari tiga hal, yaitu: pertama, perbedaan subkultur (subculture diversity), yaitu individu atau sekelompok masyarakat yang hidup dengan cara pandang dan kebiasaan yang berbeda dengan komunitas besar dengan sistem nilai atau budaya pada umumnya yang berlaku. Kedua, perbedaan dalam perpektif (perspectival diversity), yaitu individu atau kelompok dengan perpektif kritis terhadap mainstream nilai atau budaya mapan yang dianut oleh mayoritas masyarakat di sekitarnya. Ketiga, perbedaan komunalitas (communal diversity), yakni individu atau kelompok yang hidup dengan gaya hidup yang genuine sesuai dengan identitas komunal mereka (indigeneous people way of life). Sebagai sebuah gerakan, menurut Bhikhu Parekh, baru sekitar 1970-an multikulturalisme muncul pertama kali di Kanada dan Australia, kemudian di Amerika Serikat, Inggris, Jerman, dan lainnya. Setelah itu, diskursus multikulturalisme berkembang dengan sangat cepat.

Setelah tiga dekade sejak digulirkan, multikulturalisme sudah mengalami dua gelombang penting, pertama, multikulturalisme dalam konteks perjuangan pengakuan budaya yang berbeda. Prinsip kebutuhan terhadap pengakuan (needs of recognition) adalah ciri utama dari gelombang pertama ini. Gelombang kedua, adalah multikulturalisme yang melegitimasi keragaman budaya, yang mengalami beberapa tahapan, diantaranya: 2 Kebutuhan atas pengakuan, melibatkan berbagai disiplin akademik lain, pembebasan melawan imperialisme dan kolonialisme, gerakan pembebasan kelompok identitas dan masyarakat asli/masyarakat adat (indigeneous people), post-kolonialisme, globalisasi, postnasionalisme, post-modenisme dan post-strukturalisme yang mendekonstruksi stuktur kemapanan dalam masyarakat. Multikulturalisme gelombang kedua ini,

\footnotetext{
${ }^{2}$ H.A.R. Tilaar, Multikulturalisme; Tantangan-Tantangan Global Masa Depan dalam Transformasi Pendidikan Nasional (Jakarta: Grasindo, 2002), 83.
} 
menurut Steve Fuller pada gilirannya memunculkan tiga tantangan yang harus diperhatikan sekaligus harus diwaspadai, yaitu, pertama adanya hegemoni barat dalam bidang politik, ekonomi, sosial dan ilmu pengetahuan.

Komunitas, utamanya negara-negara berkembang, perlu mempelajari sebab-sebab dari hegemoni barat dalam bidang-bidang tersebut dan mengambil langkah-langkah seperlunya mengatasinya, sehingga dapat sejajar dengan dunia barat. Kedua, esensialisasi budaya. Dalam hal ini multikulturalisme berupaya mencari esensi budaya tanpa harus jatuh ke dalam pandangan yang xenophobia dan etnosentrisme. Multikulturalisme dapat melahirkan tribalisme yang sempit yang pada akhirnya merugikan komunitas itu sendiri di dalam era globalisasi. Ketiga, proses globalisasi, bahwa globalisasi bisa memberangus identitas dan kepribadian suatu budaya. ${ }^{3}$

Untuk menghindari kekeliruan dalam diskursus tentang multikulturalisme, Bikhu Parekh menggarisbawahi tiga asumsi mendasar yang harus diperhatikan dalam kajian ini, yaitu pertama, pada dasarnya manusia akan terikat dengan struktur dan sistem budayanya sendiri dimana dia hidup dan berinteraksi. Keterikatan ini tidak berarti bahwa manusia tidak bisa bersikap kritis terhadap sistem budaya tersebut, akan tetapi mereka dibentuk oleh budayanya dan akan selalu melihat segala sesuatu berdasarkan budayanya tersebut. Kedua, perbedaan budaya merupakan representasi dari sistem nilai dan cara pandang tentang kebaikan yang berbeda pula. Oleh karena itu, suatu budaya merupakan satu entitas yang relatif sekaligus partial dan memerlukan budaya lain untuk memahaminya. Sehingga, tidak satu budaya-pun yang berhak memaksakan budayanya kepada sistem budaya lain. Ketiga, pada dasarnya, budaya secara internal merupakan entitas yang plural yang merefleksikan interaksi antar perbedaan tradisi dan untaian cara pandang. Hal ini tidak berarti menegasikan koherensi dan identitas budaya, akan tetapi budaya pada dasarnya adalah sesuatu yang majemuk, terus berproses dan terbuka. Oleh karena itu, tepat kiranya jika Parekh menulis: "a culture's relation to pluralities presuppose and reinforce each other. A culture cannot appreciate the value of other unless it appreciates the plurality within it"

Sebagai sebuah cara pandang sekaligus gaya hidup, multikulturalisme menjadi gagasan yang cukup kontekstual dengan realitas masyarakat kontemporer saat ini. Prinsip mendasar tentang kesetaraan, keadilan, keterbukaan, pengakuan terhadap perbedaan adalah prinsip nilai yang dibutuhkan manusia di tengah himpitan budaya global. Oleh karenanya sebagai

\footnotetext{
${ }^{3}$ H.A.R. Tilaar, Multikulturalisme; Tantangan-Tantangan Global, 84-85.
} 
sebuah gerakan budaya, multikulturalisme adalah bagian integral dalam pelbagai sistem budaya dalam masyarakat yang salah satunya dalam pendidikan, yaitu melalui pendidikan yang berwawasan multikulturalisme.

Pendidikan dengan wawasan mutlikulturalisme dalam rumusan James A. Bank adalah konsep, ide atau falsafah sebagai suatu rangkaian kepercayaan (set of believe) dan penjelasan yang mengakui dan menilai pentingnya keragaman budaya dan etnis di dalam membentuk membentuk gaya hidup, pengalaman sosial, identitas pribadi, kesempatan-kesempatan pendidikan dari individu, kelompok maupun negara. Sementara menurut Sonia Nieto, pendidikan berwawasan multikulturalisme adalah proses pendidikan yang komperhensif dan mendasar bagi semua peserta didik. Jenis pendidikan ini menentang bentuk rasisme dan segala bentuk diskriminasi di sekolah, masyarakat dengan menerima serta mengafirmasi pluralitas (etnik, ras, bahasa, agama, ekonomi, gender dan lain sebagainya) yang terrefleksikan diantara peserta didik, komunitas mereka, dan guru-guru. Menurutnya, pendidikan berwawasan multikulturalisme ini haruslah melekat dalam kurikulum dan strategi pengajaran, termasuk juga dalam setiap interaksi yang dilakukan diantara para guru, murid dan keluarga serta keseluruhan suasana belajar mengajar.

Karena jenis pendidikan ini merupakan pedagogi kritis, refleksi dan menjadi basis aksi perubahan dalam masyarakat, pendidikan multikulturalisme mengembangkan prisip-prinsip demokrasi dalam berkeadilan sosial. Sementara itu, Bikhu Parekh mendefinisikan pendidikan multikultural sebagai: "an education in freedom, both in the sense of freedom from ethnocentric prejudices and biases, and freedom to explore and learn from other cultures and perpectives".4

Dari dua definisi diatas, hal yang harus digarisbawahi dari diskursus multikulturalisme dalam pendidikan adalah identitas, keterbukaan, diversitas budaya dan transformasi sosial. Identitas sebagai salah satu element dalam pendidikan mengandaikan bahwa peserta didik dan guru merupakan satu individu atau kelompok yang merepresentasikan satu kultur tertentu dalam masyarakat. Identitas pada dasarnya inheren dengan sikap pribadi ataupun kelompok masyarakat, karena dengan identitas tersebutlah, mereka berinteraksi dan saling mempengaruhi satu sama lain, termasuk pula dalam interaksi antar budaya yang berbeda.

Dengan demikian dalam pendidikan multikultur, identitas-identitas tersebut diasah melalui interaksi, baik internal budaya (self critic) maupun eksternal budaya. Oleh karena itu, identitas lokal atau budaya lokal merupakan

${ }^{4}$ Bikhu Parekh, Rethinking Multiculturalism: Cultural Diversity and Political Theory (Cambridge: Harvard University Press, 2000), 230. 
muatan yang harus ada dalam pendidikan multikultur. Dalam masyarakat ditemukan pelbagai individu atau kelompok yang berasal dari budaya berbeda, demikian pula dalam pendidikan, diversitas tersebut tidak bias dielakkan.

Diversitas budaya itu bisa ditemukan di kalangan peserta didik maupun para guru yang terlibat secara langsung atau tidak dalam satu proses pendidikan. Diversitas juga bisa ditemukan melalui pengkayaan budaya-budaya lain yang ada dan berkembang dalam konstelasi budaya, lokal, nasional dan global. Jadi, pendidikan berwawasan multikulturalisme bukan merupakan satu bentuk pendidikan monokultur, akan tetapi model pendidikan yang berjalan di atas rel keragaman. Diversitas budaya ini akan mungkin tercapai dalam pendidikan jika pendidikan itu sendiri mengakui keragaman yang ada, bersikap terbuka (openess) dan memberi ruang kepada setiap perbedaan yang ada untuk terlibat dalam satu proses pendidikan.

Dalam pelaksanaannya, Banks menjelaskan lima dimensi yang harus ada, pertama, adanya integrasi pendidikan dalam kurikulum (content integration) yang didalamnya melibatkan keragaman dalam satu kultur pendidikan yang tujuan utamanya adalah menghapus prasangka. Kedua, konstruksi ilmu pengetahuan (knowledge construction) yang diwujudkan dengan mengetahui dan memahami secara komperhensif keragaman yang ada. Ketiga, pengurangan prasangka (prejudice reduction) yang lahir dari interaksi antar keragaman dalam kultur pendidikan. Keempat, pedagogik kesetaraan manusia (equity pedagogy) yang memberi ruang dan kesempatan yang sama kepada setiap element yang beragam. Kelima, pemberdayaan kebudayaan sekolah (empowering school culture). Hal yang kelima ini adalah tujuan dari pendidikan multikultur yaitu agar sekolah menjadi element pengentas sosial (transformasi sosial) dari struktur masyarakat yang timpang kepada struktur yang berkeadilan.

Sementara itu, H.A.R. Tilaar menggariswahi bahwa model pendidikan yang dibutuhkan di Indonesia harus memperhatikan enam hal, pertama, pendidikan Multikulturalisme haruslah berdismensi "right to culture" dan identitas lokal. Kedua, kebudayaan Indonesia yang menjadi, artinya kebudayaan Indonesia merupakan Weltanshauung yang terus berproses dan merupakan bagian integral dari proses kebudayaan mikro. Oleh karena itu, perlu sekali untuk mengoptimalisasikan budaya local yang beriringan dengan apresiasi terhadap budaya nasional. Ketiga, pendidikan multikulturalisme normatif yaitu model pendidikan yang memperkuat identitas nasional yang terus menjadi tanpa harus menghilangkan identitas budaya lokal yang ada. Keempat, pendidikan multikulturalisme merupakan suatu rekonstruksi sosial, artinya pendidikan multikulturalisme tidak boleh terjebak pada xenophobia, fanatisme dan fundamentalisme, baik etnik, suku, ataupun agama. Kelima, pendidikan 
multikulturalisme merupakan pedagogic pemberdayaan (pedagogy of empowerment) dan pedagogik kesetaraan dalam kebudayaan yang beragam (pedagogy of equity).

Pedagogik pembedayaan pertama-tama berarti, seseorang diajak mengenal budayanya sendiri dan selanjutnya digunakan untuk mengembangkan budaya Indonesia di dalam bingkai negara-bangsa Indonesia. Dalam upaya tersebut diperlukan suatu pedagogik kesetaraan antar-individu, antar suku, antar agama dan beragam perbedaan yang ada. Keenam, pendidikan multikulturalisme bertujuan mewujudkan visi Indonesia masa depan serta etika bangsa. Pendidikan ini perlu dilakukan untuk mengembangkan prinsip-prinsip etis (moral) masyarakat Indonesia yang dipahami oleh keseluruhan komponen sosial-budaya yang plural..$^{5}$

\section{B. Singkat H. A. R Tilaar}

H. A. R Tilaar dilahirkan di Tondana, Sulawesi Utara pada 16 Juni 1932. Ia berasal dari keluarga guru. Menamatkan pendidikan dasarnya di sekolah rakyat masa kolonial, kemudian ia memasuki sekolah pedagogik pendidikan guru dan lulus dengan pujian tahun 1950 dan 1952. Dengan bekerja sebagai guru ia belajar dan memperoleh ijazah (B-I dan B-II) kedua-duanya dengan pujian pada tahun 1957 dan 1959 di Bandung. Ia memperoleh gelar sarjana pendidikannya dari Universitas Indonesia dengan predikat cumlaude pada tahun 1961.

Pada tahun 1964 ia memperoleh beasiswa dari USAID dan belajar di University of Chicago (1964-1965), kemudiain di Indiana University, Bloomington, di mana ia memperoleh master of science of education (1967) dan doctor of education (1969). Sesudahnya ia mengikuti berbagai program postgraduate di beberapa universitas di Amerika Serikat dan Inggris dan pelatihan-pelatihan di lembaga-lembaga United Nations serta IBRD dan ADB.

Sebagaimana diuraikan di atas, Tilaar meneruskan belajar dan memperoleh ijazah Pedagogik (B-I dan B-II) pada tahun 1957 dan 1959 di Bandung, dan dua tahun kemudian (1961) memperoleh gelar sarjana pendidikannya dari Universitas Indonesia dengan predikat cumlaude, ia juga sambil bekerja sebagai guru.

Tilaar telah bekerja sebagai guru sejak tahun 1952, dari sekolah rakyat sampai guru besar, dan ia minta dipensiunkan sebagai pegawai negeri pada tahun 1997 sesudah mengabdi selama 45 tahun. Sebagai seorang penulis buku-buku mengenai pedagogik, ia telah menerbitkan banyak tulisan. Ia telah mengunjungi banyak negara di dunia, menghadiri berbagai pertemuan ilmiah di dalam maupun

5 Tilaar, Multikulturalisme; Tantangan-Tantangan Global, 185-190. 
di luar negeri mengenai pendidikan. Ia adalah anggota pendiri Yayasan Buku Utama, anggota Badan Pengembangan Buku Nasional, anggota Dewan Riset Nasional (1999-2004).

Dalam birokrasi pemerintah ia adalah staf inti Badan Perencanaan Pembangunan Nasional (BAPPENAS) sejak 1970 sampai ia pensiun tahun 1993 sebagai Asisten Menteri Bidang Pengembangan Sumber Daya Manusia. Atas jasajasanya kepada negara, pada tahun 1998 ia dianugerahi Bintang Jasa Utama Republik Indonesia. Biografinya tercantum dalam Ensiklopedia Pendidikan (2001); Who's Who in The World, Millenium Edition 2000, American Biographical Institute; 1000 Great Asians, International Biographical Center, England, 2003.

Tilaar pernah terpilih sebagai penerima 2003 Man of The Year Commemorative Medal dari American Biographical Institute. Biografinya tercantum juga dalam Who's Who in American Education 2004 - 2005. Pada September 2009, ia menerima penghargaan tertinggi dari Indiana University atas pengabdiannya di bidang pendidikan yang jarang ada duanya.

Selain mengabdikan dirinya kepada Negara sebagai guru selama 45 tahun Tilaar juga seorang penulis yang sangat produktif, terutama mengenai buku-buku pedagogik. Diantara karya Prof. H.A.R. Tilaar adalah dalam bidang akademik ia telah menulis lebih dari 200 artilkel. Sedangkan buku-buku yang telah dipublikasikan adalah:

1. Manajemen dalam Pembangunan Nasional Menyosong Abad XXI. Balai Pustaka, 1990.

2. Manajemen Pendidikan Nasional. Kajian Pendidikan Masa Depan. Rosdakarya, 1992.

3. Analisis Kebijakan Pendidikan (karya bersama). Rosdakarya, 1993.

4. Lima Puluh Tahun Pendidikan Nasional : 1945-1995, Suatu Analisis Kebijakan. Gramedia, 1995.

5. Pengembangan Sumber Daya Manusia dalam Era Globalisasi: Visi, Misi, dan Program Aksi Pendidikan dan Pelatihan Menuju 2020. Gramedia, 2001.

6. Beberapa Agenda Reformasi Pendidikan Nasional. Indonesia Tera, 1998, 2001.

7. Pendidikan Kebudayaan, dan Masyarakat Madani Indonesia. Rosdakarya, 1999.

8. Paradigma Baru Pendidikan Nasional. Rineka Cipta, 2000.

9. Ide-ide Besar Oom Sam Ratulangi. Lembaga manajemen Universitas Negeri Jakarta, 2001.

10. Membenahi Pendidikan Nasional. Rineka Cipta, 2002.

11. Perubahan Sosial dan Pendidikan. Pengantar Pedagogik Transformatif untuk Indonesia, Gramedia, 2002.Kultural. Indonesia Tera, Megelang 
12. Kekuasaan dan Pendidikan Suatu Tinjauan dari Perspektif Studi, 2003.

13. Multikulturalisme. Tantangan-tantangan Global Masa Depan dalam Transformasi Pendidikan Nasional. Grasindo, Jakarta, 2004.

14. Manifesto Pendidikan Nasional, Tinjauan dari Persepektif Posmoderenisme dan Studi Kultural. Penerbit Buku Kompas, Jakarta 2005.

15. Standarisasi Pendidikan Nasional. Rineka Cipta, Jakarta, 2006.

16. Mengindonesiakan Etnisitas dan Identitas Bangsa Indonesia. Rineka Cipta, Jakarta, 2007.6

Dalam konteks masyarakat yang multidimensi diperlukan apa yang disebut sebagai menghargai serta pengelolaan yang maksimal akan keberagaman tersebut. Sebagaimana yang dipaparkan oleh Tilaar bahwa keberagaman yang ada dapat menjadi power jika dikelola dengan benar.

Lebih jelas dikemukakan bahwa dalam pembahasan tentang konsep pendidikan multikultural ada core idea (ide inti) yang ingin dipaparkan berdasarkan atas pemikiran Tilaar yakni demokrasi, humanisme, dan pluralisme. Dalam memamahami konsep pendidikan multikultural dari Tilaar akan mengacu pada core idea, sehingga akan mudah memahami konsep pendidikan multikultural.

Jika diterjemahkan dalam program pendidikan, maka ada beberapa hal yang harus dilakukan oleh guru dan siswa sebagai komponen dalam pendidikan sebagai wadah transfer of values. Diantaranya adalah : Pertama, Guru memberikan kesempatan yang sama kepada siswa tanpa memandang perbedaan baik agama, suku, ras, bahkan gender sekalipun. Kedua, Guru memfasilitasi siswa dalam berinteraksi dengan kelompok lain atau individu yang berbeda kulturnya. Sedangkan siswa harus mampu belajar untuk memahami segala perbedaan yang ada di lingkungan, baik sekolah, lingkungannya. Dan, siswa harus mampu belajar atau memahami studi lintas, baik.

Selain program diatas, ada beberapa hal yang memiliki keterikatan dengan pendidikan multikultural, khususnya dalam pandangan Islam. Seperti diketahui bahwa inti pendidikan (agama) Islam seperti yang dituliskan Abdul Munir Mulkan adalah tauhid atau aqidah. Tujuan pembelajaran bidang ini adalah untuk membentuk keyakinan tauhid peserta didik tentang ke-Esa-an Tuhan, yaitu Allah. Kaitan pendidikan multikultural dalam pelaksanaannya, ${ }^{7}$ menurut Abdul Munir Mulkhan, mengandaikan sekolah dan kelas dikelola sebagai suatu simulasi arena hidup nyata yang plural, terus berubah dan berkembang. Institusi sekolah dan

${ }^{6}$ H.A.R. Tilaar, Mengindonesiakan Etnisitas dan Identitas Bangsa Indonesia (Jakarta: Rineka Cipta, 2007), 342.

7 Abdul Munir Mulkhan, Multikulturalisme: Pendidikan Monokultural dalam Politik, http://www.atmajaya.ac.id . 
kelas adalah wahana hidup dengan pemeran utama peserta didik di saat guru dan seluruh tenaga kependidikan berperan sebagai fasilitator. Pembelajaran dikelola sebagai dialog dan pengayaan pengalaman hidup unik, sehingga bisa tumbuh pengalaman dan kesadaran kolektif setiap warga dan peserta didik yang kelak menjadi dasar etika politik berbasis etika kewargaan.

Pendidikan multikultural tersebut didasari konsep kebermaknaan perbedaan secara unik pada tiap orang dan masyarakat. Kelas disusun dengan anggota kian kecil hingga tiap peserta didik memperoleh peluang belajar semakin besar sekaligus menumbuhkan kesadaran kolektif di antara peserta didik. Pada tahap lanjut menumbuhkan kesadaran kolektif melampaui batas teritori kelas, kebangsaan dan nasionalitas, dan bahkan melampaui batas teritori teologi keagamaan dari tiap agama yang berbedadikan tauhid dengan multikultural adalah adanya penerimaan pluralisme keagamaan yang mengharuskan pengubahan tujuan pendidikan (agama) Islam baik secara makro atau mikro. Tujuan pendidikan tauhid perlu disusun dalam rumusan kultural bukan doktrinal atau struktural. Tujuan pendidikan tauhid lalu menjadi menumbuhkan kesadaran dan komitmen atas ketuhanan. Bidang ini lebih pada pengkayaan pengalaman bertuhanan dan mengalahkan tradisi setan atau kekafiran, bukan isolasi peserta didik atau maslah kekafiran. ${ }^{8}$

Tilaar berasal dari Bangsa Indonesia sejak awal bahkan sebelum masa kolonialisme. Dan tidak hanya itu, pada dasarnya lebih dari 300 suku di Indonesia yang memiliki keunikan masing-masing, sehingga hal tersebut sejak awal kemerdekaan tidak pernah dihapus. Bahkan secara formal lambang Pancasila sebagai falsafah hidup bangsa ini tertera "Bhineka Tunggal Ika" yang memiliki makna bahwa apapun perbedaan setiap masyarakat tetap memiliki tujuan yang sama. Hal ini merupakan menjadi landasan untuk mengembangkan pendidikan multikultural.

Dengan keragaman Bangsa Indonesia, maka seharusnya lebih mudah untuk mengelolanya agar menjadi power. Namun sampai hari ini disintegrasi bangsa masih terdengar dan berusaha untuk menyatukan seluruh masyarakat Indonesia. Jika ditelusuri terjadinya hal tersebut menjadikan masyarakat tersebut adalah tidak adanya penyatu bangsa dalam keberagamannya, misalnya budaya Indonesia atau budaya Nusantara. Hal ini sangat urgent yang nantinya dapat menjadi pegangan bagi generasi selanjutnya. Oleh sebab itu pendidikan multikultural yang saat ini dapat meminimalisir disintegrasi dan konflik yang ada karena sebab perbedaan suku, kultur, agama dan lainnya. Karena secara legal

\footnotetext{
${ }^{8}$ Abdul Munir Mulkhan, Kesalehan Multikultural: Ber-Islam Secara Autentik-Kontekstual di Atas Peradaban Global (Jakarta: PSAP, 2005), 181-182.
} 
formal pendidikan nasional mengemban visi dan misi integrasi nasional, martabat kemanusiaan, spiritual dan moralitas bangsa, kecerdasan, dan kecakapan hidup. Kelima visi dan misi ini harus mengejewantah kedalam seluruh satuan sistem pendidikan nasional sebagai sebuah usaha proyeksi masadepan bangsa yang lebih baik. Artinya, segenap manusia yang terlibat dalam proyek pendidikan harus mengacu kearah visi dan misi diatas. Mulai dari pemerintah, masyarakat, dan bangsa ini secara keseluruhan dan bersama-bersama.

Pendidikan multikultural dalam pandangan Tilaar benar-benar harus mampu mewujudkan manusia cerdas. Sehingga ia merumuskan ciri-ciri utama masyarakat cerdas yang dibutuhkan oleh Indonesia, yakni:

1. Cerdik-Pandai

Dalam konteks Indonesia cerdik pandai bukan hanya sekedar memiliki ilmu pengetahuan yang up-to-date dalam masyarakat, namun lebih dari itu harus mampu memahami adat istiadat yang berlaku di masyarakat, sehingga merekalah yang nantinya akan mempertimbangkan apakah adat istiadat yang sedang hidup atau dan terpelihara telah usang sehingga perlu diperbaiki, dan mengembangkan berbagai adat istiadat lain yang lebih sesuai dengan kemajuan msyarakatnya. Mereka yang disebut dengan manusia terdidik (educated). ${ }^{9}$

2. Energik-Kreatif

Bangsa Indonesia pada masa colonial terkenal dengan bangsa pemalas, bahkan ada ungkapan bahwa orang Indonesia dapat hidup sebenggol sehari (sebenggol sama dengan 2,5 sen). Namun di era globalisasi ini kita tidak dapat lagi bersikap menerima akan pemberian alam yang murah bagi kita tetapi alam merupakan suatu ruang terbatas yang merupakan paksaan seperti ungkapan Daoed Joesoef. Pertambahan penduduk menyebabkan ruang kehidupan kita semakin lama semakin sempit, oelh karena itu kita harus mengelaola lingkungan dengan sebaik-baiknya agar bermanfaat bagi kehidupan manusia. Untuk mengolala lingkungan diperlukan manusia-manusia yang energik dan kreatif sehingga dapat membangun masyarakatnya, bahkan dapat bersaing dengan Negara lain. ${ }^{10}$

Pendidikan multikultural dapat mengembangkan kemampuankemampuan khusus yang terpendam dari banyak suku bangsa Indonesia yang terkenal sangat energik dan kreatif. Misalnya kita kenal sejarah suku bangsa Bugis dari Sulawesi Selatan yang merupakan pelaut-pelaut Yang sangat energik dan mengarungi lautan India sampai ke benua Afrika. Demikian pula kita mengenal berbagai karya budaya suku-suku budaya Bali

\footnotetext{
${ }^{9}$ Tilaar, Multikulturalisme; Tantangan-Tantangan Global, 195.

${ }^{10}$ Tilaar, Multikulturalisme; Tantangan-Tantangan Global, 197. 
dan Asmat. Komunikasi dengan suku-suku bangsa yang mempunyai kemampuan-kemampuan kreatif yang semakin meluas dari bangsa Indonesia.

3. Responsif terhadap Tuntutan Masyarakat Demokratis

Amanat Undang-undang Dasar 1945, yaitu ingin membangun suatu masyarakat demokratis. Hal ini berarti setiap masyarakat perlu memiliki sikap yang diminta oleh suatu masyarakat demokratis. Yang diminta dalam masyarakat demokratis bukan hanya sekedar perwujudan dalam bentuk institusional (lembaga perwakillan rakyat, lembaga kehakiman dan lainnya) namun yang penting adalah anggota dari masyarakat demokratis harus memiliki civic skill yaitu tingkah laku sebagai warga Negara yang baik. Pendidikan multikultural dapat menjadi wadah yang efektif di dalam mengembangkan sikap responsif terhadap tuntutan dari masyarakat demokratis.

4. Daya Guna

Anggota masyarakat yang demokratis adalah anggota yang produktif. Untuk menjadikan masyarakat yang produktif harus mempunyai kesadaran sebagai warga dari masyarakatnya. Oleh sebab itu "skilled people" merupakan syarat dari suatu masyarakat yang produktif dan demokratis. Pendidikan multikultural bukan hanya bertujuan untuk menimbulkan rasa harga diri atau identitas dari masing-masing kelompok tetapi juga kemungkinan untuk mengapresiasikan keterampilan-keterampilan spesifik yang dimilki oleh kelompok.

5. Akhlak Mulia

Masayarakat dapat bertahan jika antara kemampuan intelektual dibarengi dengan kemampuan akhlak mulia. Karena jika kita lihat sejarah bahwa pengetahuan dapat menjadi bomerang bahkan menghancurkan manusia seperti alat pemusnahan masal yang dapat merugikan orang lain. Salah satu sikap orang yang akhlak mulai adalah siakp toleransi. Toleransi artinya menghargai sesame manusia meskipun sesama manusia itu berbeda dengan dirinya dalam hal apaun.

6. Sopan Santun

Sifat-sifat yang dijelaskan diatas belum mamadai bagi seseorang yang hidup di dalam ruang multietnis dan multibudaya seperti di Indonesia. Modal utama komunikasi dalam masyarakat yang multi multietnis dan multibudaya adalah sopan santun. Karena tidak jarang terjadi perselisihan karena dianggap kurang sopan karena ia tidak memahami adat istiadat orang lain. Lebih jelas dijelaskan pada tabel berikut tentang ciri-ciri manusia cerdas yang menjadi harapan dalam pendidikan multikultural: 
Tabel 3. 1

Wujud Pengembangan Pendidikan Multikultural

\begin{tabular}{|l|l|}
\hline \multicolumn{1}{|c|}{ Sikap dan Tingkah Laku } & \multicolumn{1}{c|}{ Kompetensi } \\
\hline Cerdik-pandai (educated) & - Kemampuan analitis \\
& - Dapat mengambil pilihan \\
& - Menguasai ilmu pengetahuan \\
& - Gemar belajar \\
\hline Energik-Kreatif & - Daya kreatif \\
& - Rajin, kerja keras \\
& - Tahan uji \\
\hline Responsif terhadap & - Toleransi terhadap perbedaan \\
masyarakat & - Persatuan Indonesia Pluralistik \\
\hline Demokratis & - Inklusivisme \\
\hline Daya Guna (Skilled) & - Keterampilan yang bermanfaat \\
& - Pemanfaatan sumber daya alam \\
\hline Akhlak Mulia & - Bermoral \\
& - Antikorupsi, antikolusi \\
& - Religius subtantif \\
\hline Sopan santun & - Mengenal adat istiadat \\
& - Mengenal tata pergaulan \\
& internasional \\
\hline
\end{tabular}

\section{Multikulturalisme dalam Pendidikan Islam}

Dalam dunia pendidikan, wacana multikultural merupakan fenomena relatif baru. Pendidikan multikultural mulai dikenal setelah perang Dunia II. Dengan kata lain pendidikan multikultural merupakan gejala baru dalam pergaulan umat manusia yang mendambakan persamaan hak, termasuk hak untuk mendapatkan pendidikan yang sama, untuk semua orang (education for all).11 Demikian pula di Indonesia yang masyarakatnya terdiri dari berbagai ras, etnik, agama, suku, dan lain-lain.

Pendidikan multikultural sebagaimana yang dipaparkan Banks dalam Multicultural Education Handbook of Research adalah: "Multicultural education is a concept, a frame work, a way of thinking, a philosophical viewpoint, a value

${ }^{11}$ H. A. R. Tilaar, Paradigma Baru Pendidikan Nasional (Jakarta : PT. Rineka Cipta, 2004), cet. II, 210. 
orientation, and a set of educational nedds of culturally diverse student populations." 12

Pendidikan multikultural menurut Dickerson ${ }^{13}$ adalah sebuah sistem pendidikan yang kompleks yang memasukkan upaya mempromosikan pluralisme budaya dan persamaan sosial; program yang merefleksikan keragaman dalam seluruh wilayah lingkungan sekolah; pola staffing yang merefleksikan keragaman masyarakat, mengajarkan materi yang tidak bias, kurikulum inklusif; memastikan persamaan sumberdaya dan program bagi semua siswa sekaligus capaian akademik yang sama bagi semua siswa.

Istilah "pendidikan multikultural" dapat digunakan pada tingkat deskriptif dan normatif, yang menggambarkan isu-isu dan masalah- masalah pendidikan berkaitan dengan masyarakat multikultural. Labih jauh lagi mencakup pengertian tentang pertimbangan terhadap kebijakan-kebijakan dan strategi-strategi pendidikan dalam masyarakat multikultural. Dalam konteks deskriptif ini, maka kurikulum pendidikan multkultural harus mencakup subjek-subjek seperti: toleransi, tema-tema tentang perbedaan etno-kultural, dan agama; bahaya diskriminasi; penyelesaian konflik dan mediasi; HAM; demokrasi dan pluralitas; kemanusiaan universal dan subjek-subjek lain yang relevan. ${ }^{14}$

Dalam Pembahasan tentang pendidikan multikutural berkaitan dengan tiga hal, yaitu: 1) pendidikan multikultural sebagai konsep atau ide, 2) pendidikan multikultural sebagai sebuah gerakan, dan pendidikan multikultural sebagai sebuah proses. Ketika membahas tentang konsep pendidikan multikultural, Banks menyatakan bahwa pendidikan multikultural berarti pendidikan yang memberikan kesempatan yang sama kepada siswa (tanpa mengecualikan jenis kelamin, kelas sosial, etnis, ras, atau karakteristik budaya lain) dalam belajar di sekolah. 15

Sedangkan Gorski mendefinisikan pendidikan multikultural sebagai sebuah pendekatan yang progresif dalam mengubah pendidikan yang secara holistik membahas adanya kekurangan-kekurangan, kegagalan, dan praktikpraktik diskriminasi dalam pendidikan.

Ada beberapa dimensi pendidikan multikultural yang harus dipahami, yakni dimensi-dimensi dalam pendidikan multicultural adalah :

${ }^{12}$ H. A. R. Tilaar, Paradigma Baru Pendidikan, 123.

${ }^{13}$ Zakiyuddin Baidhawy, Pendidikan Agama Berwawasan Multikultural (Jakarta : Erlangga, 2005), 77.

${ }^{14}$ Said Agil Husain al Munawwar, Aktualisasi Nilai-nilai Qur'ani dalam Sistem Pendidikan Islam (Jakarta Selatan : Ciputat Press, 2003), 213.

15 Tobroni, dkk, Pendidikan Kewarganegaraan, Demokrasi, HAM, Civil Society, dan Multikulturalisme (Malang: Pusapom, 2007), 303. 
Nurul Hidayati

1. Content Integration

Mengintegrasikan berbagai budaya dan kelompok untuk mengilustrasikan konsep mendasar, generalisasi dan teori pada mata pelajaran/dispin ilmu.

2. The Knowledge Constraction Process

Membawa siswa untuk memahami implikasi budaya ke dalam sebuah mata pelajaran (disiplin)

3. An Equity Paedagogy

Menyesuaikan metode pengajaran dengan cara belajar siswa dalam rangka memfasilitasi prestasi akademik siswa yang beragam baik segi ras, budaya ataupun sosial.

4. Prejudice reduction

Mengidentifikasi karakteristik ras siswa dan menentukan metode pengajaran mereka. Melatih kelompok untuk berpartisipasi dalam keanggotaan olahraga, berinteraksi dengan seluruh staff dan siswa yang berbeda etnis, ras dalam upaya menciptakan budaya akademik.

Paradigma pendidikan multikultural mengisyaratkan bahwa setiap peserta didik dengan segala sifat ke-individual-annya belajar bersama dengan individu lain dan dalam kegiatan belajar tersebut perlu diciptakan suasana saling menghormati, saling toleransi dan saling memahami antara satu dengan yang lainnya. Dalam konsep keindividualan itu juga beberapa hal berikut seharusnya menjadi titik perhatian yaitu bagi para penyelenggara pendidikan bahwa:

1. Setiap siswa seharusnya mempunyai kesempatan yang sama untuk mengembangkan potensi yang dimilikinya secara penuh.

2. Setiap siswa harus disiapkan agar mampu berperan secara kompeten dalam masyarakat multi budaya.

3. Para guru harus dipersiapkan agar bisa memfasilitasi pembelajaran dari setiap ke-individual-an siswa, tidak penting seberapa jauh persamaan atau perbedaan kebiasaan/budaya dengan dirinya.

Sekolah harus lebih aktif "memerangi" segala macam bentuk "penindasan" yang terjadi di sekolah, baik yang dilakukan oleh oknum sekolah ataupun yang terjadi di kalangan siswa sendiri dengan melakukan kritik secara aktif serta memberi peringatan kepada para siswa. Pendidikan seharusnya lebih bersifat "student-centered". Pendidik, aktivis, dan yang lainnya harus berperan lebih aktif dalam menguji kembali kegiatan pendidikan yang berlangsung selama ini dan sejauh mana pengaruh pembelajaran terhadap siswa secara keseluruhan. ${ }^{16}$

16 Lihat dalam "The Challenge of Defining "Multicultural Education"," Critical Multicultural Pavilion, last modified April 14, 2010, http://www.edchange.org/multicultural/initial.html

Jurnal Pendidikan Agama Islam

Volume 4 Nomor 1 Mei 2016

ISSN(p) 2089-1946 \& ISSN(e) 2527-4511

Hal. 58 - 67 
Indonesia salah satu Negara plural yang terdiri dari berbagai ras, suku, agama, budaya menjadikan pendidikan sebagai sebagai salah satu sarana startegis dalam upaya membangun jati diri bangsa adalah sebuah langkah yang relatif tepat, dan menjanjikan pendidikan yang layak dan kelihatannya tepat dan kompatibel untuk membangun bangsa kita adalah dengan model pendidikan multikultural. berkaitan dengan hal ini, maka pendidikan multikultural menawarkan satu alternatif melalui penerapan strategi dan konsep pendidikan yang berbasis pada pemanfaatan keragaman yang ada di masyarakat, khususnya yang ada pada siswa seperti keragaman etnis, budaya, bahasa, agama, status sosial, gender, kemampuan, umur dan ras. Hal ini didasarkan pada beberapa pertimbangan berikut: Pertama, pendidikan multikultural secara inhern sudah ada sejak bangsa Indonesia ini ada. Falsafah bangsa Indonesia adalah bhineka tunggal ika, suka gotong royong, membantu, dan menghargai antar satu dengan yang lainnya. betapa dapat dilihat dalam potret kronologis bangsa ini yang sarat dengan masuknya berbagai suku bangsa asing dan terus berakulturasi dengan masyarakat pribumi. Misalnya etnis cina, etnis arab, etnis arya, etnis eropa, etnis afrika dan sebagainya. Semua suku itu ternyata secara kultural telah mampu beradaptasi dengan suku-suku asli negara Indonesia. Misalnya suku jawa, batak, minang, bugis, ambon, papua, suku dayak, dan suku sunda. Proses adaptasi dan akulturasi yang berlangsung di antara suku-suku tersebut dengan etnis yang datang kemudian itu, ternyata sebagian besar dilakukan dengan damai tanpa adanya penindasan yang berlebihan. Proses inilah yang dikenal dengan pendidikan multikultural. Hanya saja model pendidikan multikultural ini semakin tereduksi dengan adanya kolonialisasi di bibidang ploitik, ekonomi, dan mulai merambah ke bidang budaya dan peradaban bangsa.

Kedua, pendidikan multikultural memberikan secerah harapan dalam mengatasi berbagai gejolak masyarakat yang terjadi akhir-akhir ini. Pendidikan multikultural, adalah pendidikan yang senantiasa menjunjung tinggi nilai-nilai, keyakinan, heterogenitas, pluralitas dan keragaman, apapun aspeknya dalam masyarakat. Dengan demikian, pendidikan multikultural yang tidak menjadikan semua manusia sebagai manusia yang bermodel sama, berkepribadian sama, berintelektual sama, atau bahkan berkepercayaan yang sama pula.

Ketiga, pendidikan multikultural menentang pendidikan yang beroreintasi bisnis. Pada saat ini, lembaga pendidikan baik sekolah atau perguruan tinggi berlomba-lomba menjadikan lembaga pendidikannya sebagai sebuah institusi yang mampu menghasilkan income yang besar. Dengan alasannya, untuk meningkatkan kualitas pelayanan kepada peserta didik. Padahal semua orang tahu, bahwa pendidikan yang sebenarnya bagi bangsa Indonesia bukanlah pendidikan keterampilan belaka, melainkan pendidikan yang harus 
Nurul Hidayati

mengakomodir semua jenis kecerdasan, baik kecerdasan intelektual, emosional, spiritual, dan lain-lain yang sering dikenal dengan nama kecerdasan ganda (multiple intelligence). ${ }^{17}$

Keempat, pendidikan multikultural sebagai resistensi fanatisme yang mengarah pada berbagai jenis kekerasan. Kekersan muncul ketika saluran kedamaian sudah tidak ada lagi. Kekerasan tersebut sebagai akibat dari akumulasinya berbagai persoalan masyarakat yang tidak diselesaikan secara tuntas dan saling menerima. Ketuntasan penyelesaian berbagai masalah masyarakat adalah prasyarat bagi munculnya kedamaian. Fanatisme yang sempit juga bisa meyebabkan munculnya kekerasan. Dan fanatisme ini juga berdimensi etnis, bahasa, suku, agama, atau bahkan sistem pemikiran baik di bidang pendidikan, politik, hukum, ekonomi, sosial, budaya, dan aspek kehidupan lainnya.

Pendidikan multikultural di dasari konsep kebermaknaan perbedaan secara unik pada tiap orang dan masyarakat. Kelas disusun dengan anggota kian kecil hingga tiap peserta didik memperoleh peluang belajar semakin besar sekaligus menumbuhkan kesadaran kolektif di antara peserta didik. Pada tahap lanjut menumbuhkan kesadaran kolektif melampaui batas teritori kelas, kebangsaan dan nasionalitas, melampaui teritori teologi keagamaan dari tiap agama berbeda.

Gagasan itu didasari asumsi, tiap manusia memiliki identitas, sejarah, lingkungan, dan pengalaman hidup unik dan berbeda-beda. Perbedaan adalah identitas terpenting dan paling otentik tiap manusia dari pada kesamaannya. Kegiatan belajar-mengajar bukan ditujukan agar peserta didik menguasai sebanyak mungkin materi ilmu atau nilai, tetapi bagaimana tiap peserta didik mengalami sendiri proses berilmu dan hidup di ruang kelas dan lingkungan sekolah.

Gagasan pendidikan multikultural bersumber dari prinsip martabat keunikan diri tiap peserta didik. Pendidikan formal (sekolah) diletakkan dalam ide deschooling Ivan Liich seperti demokrasi yang meletakkan suara rakyat sebagai suara Tuhan. Rakyat sebagai diri lebih penting dari realitas negara dan partai seperti dalam masyarakat sipil atau madani. Kegiatan belajar mengajar bukan sebagai alat sosialisasi atau indoktrinasi guru, tetapi wahana dialog dan belajar bersama. Di saat yang sama institusi negara dan partai dikembangkan sebagai wahana aktualisasi dan representasi kepentingan rakyat. ${ }^{18}$

\footnotetext{
${ }^{17}$ Tilaar, Paradigma Baru Pendidikan Nasional, 208.

18 "Pendidikan Multikultural," Multikulturalisme dan Pendidikan Multikultural,ditulis 27 Mei 2004, http://tulisanterkini.com/artikel/pendidikan/2982-multikulturalisme-dan-pendidikanmultikultural.html\#top .
} 
Oleh karena itulah sekolah harus menjadi pusat keanekaragaman dan sejarah Indonesia dalam beberapa aspek seperti keanekaragaman budaya, sejarah, dan kondisi masyarakat Indonesia secara kontekstual. Aspek-aspek ini pula merupakan komponen utama yang harus dimuat dalam kurikulum pendidikan multikultural.

Semangat pluralisme yang telah dibangun sejak berdirinya Boedi Oetomo pada tahun 1908, menanamkan kesadaran akan kebangsaan dalam pluralitas. Sumpah Pemuda 1928 merupakan sumpah dan komitmen tentang pluralisme itu sendiri, yaitu kesadaran akan pluralisme sebagai sebuah "utopia” bangsa di masa depan. Penyatuan pluralitas lewat konsep bangsa (collective self), bahasa (symbolic), dan tanah air (territorial) di dalamnya tidak melenyapkan berbagai perbedaan elemen-elemen plural yang membangunnya. Semangat dan jiwa pluralisme dalam kesatuan terus dibangun pada era perjuangan mempertahankan kemerdekaan 1945-1949. sayangnya, tragedi politik 1966 menyebabkan telantarnya perjuangan ke arah pluralisme tersebut.

Multikulturalisme (multiculturalism), meskipun berkaitan dan sering disamakan adalah kecenderungan yang berbeda dengan pluralisme. Multikulturalisme adalah sebuah relasi pluralitas yang di dalamnya terdapat problem minoritas (minority groups) versus mayoritas (mayority group), yang didalamnya ada perjuangan eksistensial bagi pengakuan, persamaan (equqlity), kesetaraan, dan keadilan (justice), seperti perjuangan yang dilakukan oleh kelompok minoritas Afrika, India, Pakistan, cina, Turki di Amerika Serikat. Multikulturalisme jelas memperkaya pluralisme, meskipun tidak bisa disamakan dengannya. ${ }^{19}$

Rancangan ke depan pendidikan multikultural adalah perlunya membangun perubahan orientasi. Pendidikan multikultural harus dipromosikan secara terus-menerus dan hal ini jelas merupakan suatu perubahan orientasi pendidikan dan masyarakat. Bangsa Indonesia di kenal sebagai bangsa majemuk, ditandai dengan banyaknya etnis, suku, agama, budaya, kebiasaan, di dalamnya. Di sisi lain masyarakat Indonesia di kenal sebagai masyarakat multikultural, masyarakat yang anggotanya memiliki latar belakang budaya (cultural background) beragam.

\section{Mendesain Pendidikan Islam Multikultural}

Menyusun pendidikan Islam berwawasan multikulturalisme dalam tatanan masyarakat yang penuh permasalahan antar kelompok mengandung tantangan yang tidak ringan. Pendidikan Islam berwawasan multikulturalisme

${ }^{19}$ Multikulturalisme dan Pendidikan Multikultural , "Pendidikan Multikultural," 
tidak berarti sebatas "merayakan keragaman" belaka. Apalagi jika tatanan masyarakat yang ada masih penuh diskriminasi dan bersifat rasis. Dapat pula dipertanyakan apakah mungkin meminta siswa yang dalam kehidupan sehari-hari mengalami diskriminasi atau penindasan karena warna kulitnya atau perbedaannya dari budaya yang dominan tersebut?. Dalam kondisi demikian pendidikan Islam berwawasan multikulturalisme lebih tepat diarahkan sebagai advokasi untuk menciptakan masyarakat yang toleran dan bebas toleransi.

Ada beberapa pendekatan dalam proses pendidikan Islam berwawasan multikulturalisme sebagai pola pembelajaran, yaitu: Pertama, tidak lagi terbatas pada menyamakan pandangan pendidikan (education) dengan persekolahan (schooling) atau pola pembelajaran berwawasan multikulturalisme dengan program-program sekolah formal. Pandangan yang lebih luas mengenai pendidikan sebagai transmisi kebudayaan membebaskan pendidik dari asumsi bahwa tanggung jawab primer mengembangkan kompetensi kebudayaan di kalangan anak didik semata-mata berada di tangan mereka dan justru semakin banyak pihak yang bertanggung jawab karena program-program sekolah seharusnya terkait dengan pembelajaran informal di luar sekolah. ${ }^{20}$

Kedua, menghindari pandangan yang menyamakan kebudayaan kebudayaan dengan kelompok etnik adalah sama. Artinya, tidak perlu lagi mengasosiasikan kebudayaan semata-mata dengan kelompok-kelompok etnik sebagaimana yang terjadi selama ini. secara tradisional, para pendidik mengasosiasikan kebudayaan hanya dengan kelompok-kelompok sosial yang relatif self sufficient, ketimbang dengan sejumlah orang yang secara terus menerus dan berulang-ulang terlibat satu sama lain dalam satu atau lebih kegiatan. Dalam konteks pola pembelajaran berwawasan multikulturalisme, pendekatan ini diharapkan dapat mengilhami para penyusun program-program pembelajaran berwawasan multikulturalisme untuk melenyapkan kecenderungan memandang anak didik secara stereotip menurut identitas etnik mereka dan akan meningkatkan eksplorasi pemahaman yang lebih besar mengenai kesamaan dan perbedaan di kalangan anak didik dari berbagai kelompok etnik. ${ }^{21}$

Ketiga, karena pengembangan kompetensi dalam suatu kebudayaan baru biasanya membutuhkan interaksi inisiatif dengan orang-orang yang sudah memiliki kompetensi, bahkan dapat dilihat lebih jelas bahwa upaya-upaya untuk mendukung sekolah-sekolah yang terpisah secara etnik adalah antitesis terhadap tujuan pembelajaran berwawasan multikulturalisme. Mempertahankan dan memperluas solidarits kelompok adalah menghambat sosialisasi ke dalam

\footnotetext{
${ }^{20}$ Multikulturalisme dan Pendidikan Multikultural , "Pendidikan Multikultural,"

${ }^{21}$ Multikulturalisme dan Pendidikan Multikultural , "Pendidikan Multikultural," 
kebudayaan baru. Pendidikan bagi pluralisme budaya dan pembelajaran berwawasan multikulturalisme tidak dapat disamakan secara logis.

Keempat, pola pembelajaran berwawasan multikulturalisme meningkatkan kompetensi dalam beberapa kebudayaan. Kebudayaan mana yang akan diadopsi ditentukan oleh situasi. Kelima, kemungkinan bahwa pendidikan (baik dalam maupun luar sekolah) meningkatkan kesadaran tentang kompetensi dalam beberapa kebudayaan. Kesadaran seperti ini kemudian akan menjauhkan kita dari konsep dwi budaya atau dikotomi antara pribumi dan non-pribumi. Dikotomi semacam ini bersifat membatasi individu untuk sepenuhnya mengekspresikan diversitas kebudayaan. Pendekatan ini meningkatkan kesadaran akan multikulturalisme sebagai pengalaman normal manusia. Kesadaran ini mengandung makna bahwa pembelajaran berwawasan multikulturalisme berpotensi untuk menghindari dikotomi dan mengembangkan apresiasi yang lebih baik melalui kompetensi kebudayaan yang ada pada diri anak didik.

Dalam konteks keindonesiaan dan kebhinekaan, kelima pendekatan tersebut haruslah diselaraskan dengan kondisi masyarakat Indonesia. Masyarakat adalah kumpulan manusia atau individu-individu yang terjewantahkan dalam kelompok sosial dengan suatu tantangan budaya atau tradisi tertentu. Masyarakat secara sederhana diartikan sebagai kumpulan individu dan kelompok yang diikat oleh kesatuan negara, kubudayaan dan agama.

Jadi, dapat dipahami inti masyarakat adalah kumpulan besar individu yang hidup dan bekerja sama dalam masa relatif lama, sehingga individu-individu dapat memenuhi kebutuhan mereka dan menyerap watak sosial. Kondisi itu selanjutnya membuat sebagian mereka menjadi komunitas terorganisir yang berpikir tentang dirinya dan membedakan ekstensinya dari ekstensi komunitas. Dari sisi lain, apabila kehidupan di dalam masyarakat berarti interaksi antara individu dan lingkungan sosialnya. Maka yang menjadikan pembentukan individu tersebut adalah pendidikan atau dengan istilah lain masyarakat pendidik. ${ }^{22}$

Oleh karena itu, dalam melakukan kajian dasar kependidikan terhadap masyarakat. Secara garis besar dasar-dasar yang dimaksud adalah sebagai berikut:

1. Masyarakat tidak ada dengan sendirinya. Masyarakat adalah ekstensi yang hidup, dinamis, dan selalu berkembang.

2. Masyarakat bergantung pada upaya setiap individu untuk memenuhi kebutuhan melalui hubungan dengan individu lain yang berupaya memenuhi kebutuhan.

${ }^{22}$ Multikulturalisme dan Pendidikan Multikultural , "Pendidikan Multikultural," 
3. Individu-individu, di dalam berinteraksi dan berupaya bersama guna memenuhi kebutuhan, melakukan penataan terhadap upaya tersebut dengan jalan apa yang disebut tantangan sosial. Setiap masyarakat bertanggung jawab atas pembentukan pola tingkah laku antara individu dan komunitas yang membentuk masyarakat.

4. Pertumbuhan individu di dalam komunitas, keterikatan dengannya, dan perkembangannya di dalam bingkai yang menuntunnya untuk bertanggung jawab terhadap tingkah lakunya. ${ }^{23}$

Pendidikan Islam berwawasan multikulturalisme bukan suatu hal yang taken for granted, namun membutuhkan usaha yang sistematis sehingga benarbenar akan terciptanya masyarakat yang dapat saling bergandengan dalam suatu struktur masyarakat. Berbagai upaya termasuk orientasi, pendekatan yang dipaparkan oleh Baidhawy merupakan gagasan yang kongkrit dalam mewujudkan pendidikan Islam berwawasan multikulturalisme. Namun, menurut hemat penulis ada hal yang sangat penting dalam mewujudkan pendidikan Islam berwawasan multikulturalisme melalui pola pembelajarannya, yakni kemampuan guru terhadap pengetahuan keberagaman serta isu-isu sosial keagamaan. Oleh sebab itu, sebelum memasuki ranah muatan, siswa, dan sosial, yang perlu dipertanyakan adalah kemamapuan guru dalam mentansformasikan pendidikan berwawasan multikulturalisme. Walaupun guru bukanlah pemegang otiritas, namun guru sebagi fasilitator harus mampu mendesain pembelajaran dan memfasilitasi kebutuhan siswa, termasuk kebutuhan akan pengetahuan keberagaman, baik budaya, etnik ataupun agama. Dengan demikian dalam hal ini harus ada kerjasama struktural antara guru dengan pemerintah sebagai pengambil kebijakan nasional.

Untuk mengembangkan desain (pola) pembelajaran berwawasan multikulturalisme diperlukan sebuah cara dalam menerjemahkan sebuah pendekatan, metode dan selanjutnya dikembangkan beberapa strategi yang konsisten dengan metode dan pendekatan yang diambil. Pembelajaran berwawasan multikulturalisme merupakan sebuah prosedur (metode) untuk melembagakan (instutisionalisasi) filosofi kebinekaan budaya di sekolah. Pada umumnya sebuah budaya mengacu pada sebuah situasi dan keadaan bukan sebuah tujuan. Salah satu definisi kebinekaan budaya yang diadopsi dari The National Coalition of Cultur Pluralism adalah sebagai berikut:

"Cultural pluralism refers to a state of equel co-existence in mutually realitionship within the boundaries of framework of one nation of people of

\footnotetext{
${ }^{23}$ Multikulturalisme dan Pendidikan Multikultural , "Pendidikan Multikultural," 
diverse cultures, with signicicantly different patterns of belief, behavior, color and many cases with defferent languages". 24

Untuk dapat disebut pluralisme budaya, maka harus terjadi ke-ekaan dalam kebinekaan. Masing-masing orang harus sadar akan jati dirinya dan mengamankan jati dirinya tersebut, serta menghormasti budaya sendiri. Yang Pluralisme memvisikan sebuah masyarakat multietnik yang saling menghormati dan mengapresiasi berbagai budaya, dan memiliki hak yang sama dalam kerangka pelestarian dan pengembangan tradisi budaya masing-masing. Namun definisi tersebut memiliki beberapa kelemahan. 25

Untuk menerapakan pola pembelajaran berwawasan multikulturalisme model pembelajaran yang akan dikembangkan diarahkan pada kompetensikompetensi sebagai berikut:

1. Mengembangkan kompetensi akademik standar dan dasar tentang nilai-nilai persatuan dan kesatuan, demokrasi, keadilan, kebebasan, persamaan derajat atau saling menghargai dalam keragaman budaya;

2. Mengembangkan kompetensi sosial agar dapat menumbuhkan pemahaman (better understanding) tentang latar belakang budaya sendiri dan budaya lain dalam masyarakat;

3. Mengembangkan kompetensi akademik untuk menganalisis dan membuat keputusan cerdas (intelligent decision) tentang isu-isu dan masalah keseharian melalui sebuah proses demokratis atau inkuiri dialogis.

4. Membantu mengkonseptualisasikan dan mengaspirasikan sebuah masyarakat yang lebih baik, demokratis dan memiliki persamaan derajat.

\section{E. Penutup}

Dari seluruh rangkaian penelitian tentang Pendidikan Agama Islam berwawasan Multikulturalisme, maka penulis menyimpulkan bahwa : Islam adalah agama universal yang menjunjung tinggi nilai-nilai kemanusiaan, persamaan hak dan mengakui adanya keragaman latar belakang budaya dan kemajemukan. Multikultural menurut Islam adalah sebuah aturan Tuhan (sunnatullah) yang tidak akan berubah, juga tidak mungkin dilawan atau diingkari. Setiap orang akan menghadapi kemajemukan di manapun dan dalam hal apapun. Ungkapan ini menggambarkan bahwa Islam sangat menghargai multikultural karena Islam adalah agama yang dengan tegas mengakui perbedaan setiap individu untuk hidup bersama dan saling menghormati satu dengan yang lainnya.

\footnotetext{
${ }^{24}$ Triyo Supriyatno, "Medelisasi Pembelajaran Berwawasan Multikulturalisme di Indonesia," Jurnal Jabal Hikmah I, No. 1, (Januari 2008): 89.

${ }^{25}$ Triyo Supriyatno, "Medelisasi Pembelajaran," 91-92.
} 
Konsep multikulturalisme menekankan keanekaragaman kebudayaan dalam kesederajatan. Ulasan mengenai multikulturalisme akan mengulas berbagai permasalahan yang mendukung ideologi ini, yaitu politik dan demokrasi, keadilan dan penegakkan hukum, kesempatan kerja dan berusaha, Hak Asasi Manusia, hak budaya komuniti dan golongan minoritas, prinsip-prinsip etika dan moral, dan tingkat serta mutu produktivitas. Di dalam perkembangannya multikulturalisme telah mengambil dua bentuk yaitu: pertama, kebutuhan akan pengakuan di dalam masyarakat (the need of recognition) dan yang kedua ialah hak untuk berbeda (the rights to difference).

Konsep multikulturalisme harus dikembangkan dan diinternalisasikan dalam proses transformasi nilai-nilai masyarakat dan bangsa yang beragam ini. Sarana terbaik dan strategis yang digunakan untuk membangun dan mensosialisasikan konsep multikulturalisme agar melahirkan perilaku sosial kondusif, kearifan sosial, kearifan budaya dan kearifan moral atau akhlak melalui pendidikan multikulturalisme yang merupakan sebuah prosedur (metode) untuk melembagakan (instutisionalisasi) filosofi kebinekaan budaya di sekolah.

\section{F. Referensi}

Baidhawy, Zakiyuddin. Pendidikan Agama Berwawasan Multikultural. Jakarta: Erlangga, 2005.

El-Ma'hady, Muhaemin. "Pendidikan Multikultural," Multikulturalisme dan Pendidikan Multikultural. 27 Mei 2004.

http://tulisanterkini.com/artikel/pendidikan/2982-multikulturalismedan-pendidikan-multikultural.html\#top.

Gorski, Paul C. The Challenge of Defining "Multicultural Education". 14 April 2010. http://www.edchange.org/multicultural/initial.html.

Mulkhan, Abdul Munir. Kesalehan Multikultural: Ber-Islam Secara AutentikKontekstual di Atas Peradaban Global. Jakarta: PSAP, 2005.

—. Multikulturalisme: Pendidikan Monokultural dalam Politik. t.thn. http://www.atmajaya.ac.id.

Munawwar, Said Agil Husain al. Aktualisasi Nilai-nilai Qur'ani dalam Sistem Pendidikan Islam. Jakarta Selatan: Ciputat Press, 2003.

Parekh, Bikhu. Rethinking Multiculturalism: Cultural Diversity and Political Theory. Cambridge: Harvard University Press, 2000.

Scott Lash dan Mike Featherstone, ed. Recognition and Difference: Politics, Identity, Multiculture. London: Sage Publication, 2002. 
Supriyatno, Triyo. "Medelisasi Pembelajaran Berwawasan Multikulturalisme di Indonesia." Jurnal Jabal Hikmah 1 (Januari 2008): 89.

Tilaar, H. A. R. Paradigma Baru Pendidikan Nasional. Jakarta: PT. Rineka Cipta, 2004.

Tilaar, H.A.R. Mengindonesiakan Etnisitas dan Identitas Bangsa Indonesia. Jakarta: Rineka Cipta, 2007.

-. Multikulturalisme; Tantangan-Tantangan Global Masa Depan dalam Transformasi Pendidikan Nasional. Jakarta: Grasindo, 2002.

Tobroni. Pendidikan Kewarganegaraan, Demokrasi, HAM, Civil Society, dan Multikulturalisme. Malang: Pusapom, 2007. 